\title{
Land Use Policy and Spatiotemporal Changes in the Water Area of an Arid Region
}

\author{
Fei Xu ${ }^{a}$, Helen X.H. Bao ${ }^{b}$, Huan Li $^{a_{*}}$, Mei-Po Kwan ${ }^{c}$, Xianjin Huang ${ }^{a_{*}}$ \\ ${ }^{a}$ Geographic and Oceanographic Sciences School, Nanjing University, Nanjing 210093, China \\ ${ }^{b}$ Department of Land Economy, University of Cambridge, Cambridge CB3 9EP, UK \\ ${ }^{c}$ Department of Geography and Geographic Information Science, University of Illinois at \\ Urbana-Champaign (UIUC), Champaign, IL 61820, USA
}

\begin{abstract}
:
In this study, we developed a framework to analyze the impact of land use policies on water area changes. We used quantitative and qualitative approaches in our model, including Delphi method, Moran's I, 3D kernel density surface (3D-KDS) technique, and orthogonalized regression. The model facilitates visual examination of spatiotemporal patterns in water area changes and identification of the net effect of land use policies on water area changes. We consider three types of land use policy and four control variables which include water management policy and climate change factors to test the model by using data from Ejina, an oasis area from Inner Mongolia, China. The results of both 3D-KDS and Moran's I coefficient showed distinctive patterns in negative and positive water area changes. Standardized coefficients from the augmented orthogonalized ordinary least squares(OLS) models helped isolate the net effects of the three types of land use policy on negative and positive water area changes. Land use policies had greater impact on hydrological environment changes than water management policy and climate change factors. Our model can be utilized to assess the effectiveness of land use policies in an area and aid in helpful in monitoring the implementation of existing policies and design of new land use policies.
\end{abstract}

Keywords: Land use policy, arid region, water area, kernel density surface, spatial autocorrelation 


\section{Land Use Policy and Spatiotemporal Changes in the Water Area of an Arid Region}

\section{Introduction}

The advancement of science and technology has greatly enhanced our ability to modify nature. Now more than ever, humans have more influence on water area changes (Mehta, 2014). The interactions between human activities and water area changes are an important international research topic that has attracted considerable attention from many research institutions and individuals worldwide (See, for example, Das et al., 2015; Gibbs, 2010; Yin et al., 2013). The International Association of Hydrological Sciences (IAHS) launched the first International Hydrological Decade (IHD) in 1965. This project aimed to promote international cooperation in research on hydrology and water resources from the perspective of rational utilization of water resources. Within a decade since its inception, the project had promoted research activities and government efforts on important issues, such as the relationship among urbanization, water resource planning, social environment, and hydrological environment changes (Nace, 1980). In 2013, IAHS launched IHD (2013-2022) at Gothenburg, Sweden. "Changes in the relationship between hydrological science and social system" was the theme of the latest IHD (Montanari et al., 2013). The impact of land use policy as an important component of social system (Li et al., 2015) has been selected as a sub-topic in IHD (2013-2022). More recently, the relationship between water resources and land uses has attracted considerable attention of the policy-makers, practitioners, and government organizations in the 2015 World Water Forum. The future development of water resource requires effective communication between scientists and policy-makers to ensure that expertise is translated into actions that address water challenges (Oki and Kanae, 2006). Sustainable land-use policies must involve management of landscape structure such as water areas (Eduful and Shively, 2015). Therefore, the inter-relationship between land use policies and water area changes at a large spatiotemporal scale is one of the key research topics for future studies.

Efforts from researchers worldwide have resulted in considerable literature on the relationship between human activities and water resource change. Existing studies can be classified broadly into qualitative and quantitative studies. Qualitative research often 
develops conceptual models by classifying specific human activities to identify causes of changes in hydrological elements, such as deterioration in water environment or frequent occurrence of flood and drought (See, for example, Jothityangkoon et al., 2013; Le Maitre et al., 2014). Subsequently, various monitoring, prevention, and alleviating suggestions have been proposed based on the analysis. This stream of research aims to promote effective public policies to slow down or stop the deterioration of the water environment. Quantitative research focuses on the analysis, prediction, and simulation of the impact of human activities on the changes in the water environment based on numerical investigations (See, for example, Das et al., 2015; Ismaiylov and Fedorov, 2001; Williams, 1989) Econometric methods, including regression analysis (Ahmed et al., 2014), Monte Carlo simulation (Shindu and Govindaru, 2014), entropy evaluation method (Shindu and Govindaru, 2014), and spatial-temporal models (Yang and Liu, 2014), have been used to identify potential impact from natural and human factors on water changes. The scientific validity and comparability of empirical findings have been improved by adopting these quantitative approaches. Commonly, a combination of quantitative and qualitative methods is used in studies, providing a comprehensive analysis of available information and data (See, for example, Chou et al., 2014; Luo et al., 2013; Zhang et al., 2013).

Urbanization brings both economic prosperity and environmental challenges in most developing countries (Cohen, 2006). Government often rely on land use planning and conservation strategies to strike a balance between economic development and sustainable water resources management, (Cobbinah et al., 2015). Not surprisingly, poor compliance with urban land use regulations can results in threats to water resources preservation. This has become a systematic urban planning problem in many developing countries (Cobbinah et al., 2015). This problem often manifests itself in the form of water areas reduction and changes of the spatial distribution of water areas. Unfortunately, water resources management in developing countries is far from adequate, which can be attributed to a wide range of reasons besides low compliance with land use regulations (UN-Habitat, 2009). These include the lack of environmental policies and regulations, poor regulatory enforcement, lack of environmental awareness and skilled personnel, conflict of interests among sectors, and financial constraints (UN-Habitat, 2009). However, the majority of the literature has not considered the role of land use policies on water area changes sufficiently (Gyau-Boakye and Biney, 2002). 
It is necessary to conduct interdisciplinary research and quantitative assessment of the role of land use policies in order to improve water resources management in developing countries (Oki and Kanae, 2006). To bridge this gap in the literature, we investigate the relationship between land use polices and water area changes.

European Environment Agency's definition of water resource changes includes water quantity changes, water quality changes, and water area changes (EEA, 2012). In this paper we focus on the changes of water area because it is most relevant to water resources management in arid regions. Moreover, in the era of the 'Anthropocene', where human impacts on land use processes are large and widespread, researchers have started to consider the impact of human interventions on water area changes (Oki and Kanae, 2006). Monitoring and understanding the direction and speed of water area changes are helpful to understand the interaction between human activities and environmental changes (Lambin and Meyfroidt, 2010). Therefore this narrow definition of water resource changes serves our research purpose well.

Following the best practice in the literature, we adopt both qualitative and quantitative approaches to investigate the impact of land use policy on spatial-temporal changes in water areas. We develop an analytical framework by employing Delphi method, Moran's I, 3D kernel density surface (3D-KDS) technique, and orthogonalized regression. This combination of qualitative and quantitative approaches enables us explore available data fully and investigate all important aspects of the issues at hand. We test our model by using data from Ejina, China, an oasis area that is prone to water area changes. Empirical evidence suggests that our model can effectively illustrate water area changes over time through a combination of graphical evidence and numerical results. The net effect of land use policy on water area changes is identified directly based on coefficient estimates from orthogonalized regression. Therefore, the developed framework will be useful for policy makers and researchers in related fields.

The rest of this paper is organized as follows. Section 2 presents the methodology. Section 3 discusses the empirical implementation. Sections 4 and 5 provide the results of spatiotemporal variations in water area changes and the impact of land use policy on water area changes, respectively. Section 6 provides the conclusions. 


\section{Methodology}

Land use policy can either encourage or discourage water area preservation. For example, if a "Green Belt" is designated by the local government, water areas within and surrounding the Green Belt will likely to be preserved, while other types of land may be converted to water land. Hence, the impact of such a land use policy is positive. Nevertheless, if industrial use land parcels are provided at a discounted price to encourage local economic growth, water areas in affected regions will likely to be converted for non-agricultural uses. The effect of such a land use policy on water area preservation is negative. We determine the impact of land use policy on hydrological environment accurately by classifying water area changes into negative changes (i.e., water areas converted to arable land, forest, grassland, desert, or construction land) and positive changes (i.e., arable land, forest, grassland, desert, or construction land converted to water areas). Without losing any generality, we define the relationship between land use policy and water area changes as

$Y_{i}=f(\boldsymbol{L}, \boldsymbol{C})$,

$i \in\{P, N\}$,

where $Y_{i}$ is the water area changes, with $P$ denotes positive changes and $N$ indicates negative changes; $\boldsymbol{L}$ is a matrix of land use policy indicators; and $\boldsymbol{C}$ is a matrix of control variables. Equation (1) assumes that water area changes (positive or negative) are affected by land use policies, holding constant the effects from other factors, such as national and local water management policies, annual precipitation and temperature. The measurements of $Y_{i}$ and $\boldsymbol{L}$ are essential to make Equation (1) operable.

The changes in water areas are gradual, typically over years or even decades. Therefore, neither cross-sectional nor time-series observations of water area changes at specific locations are adequate and appropriate to support our analysis. Instead, we need a tool to measure the intensity or concentration of positive or negative water area changes over a sufficiently long period. This approach is efficient for measuring the impact of land use policy on water area changes considering that the effect of government policy tends to be long-lasting. Spatial autocorrelation methods can be used to achieve this goal. Spatial 
autocorrelation models measure how much closer objects are similar to one another when compared with distant objects within a region. The distribution tendency of objects in space is indicated (e.g., spatially clustered or dispersed). In this study, we use a popular spatial autocorrelation indicator, Moran's I, as the measure of spatial autocorrelation by following the practice in similar studies (See, for example, Javi et al., 2014; Ou et al., 2014; Zhai et al., 2014). Moran's I is defined as

$I=\frac{N}{\sum_{i=1}^{N} \sum_{j=1}^{N} W(i, j)} \times \frac{\sum_{i=1}^{N} \sum_{j=1}^{N} W(i, j)\left(X_{i}-\bar{X}\right)\left(X_{j}-\bar{X}\right)}{\sum_{i=1}^{N}\left(X_{i}-\bar{X}\right)^{2}}$,

where $N$ is the number of spatial units included in a given area; $X$ is the variable of interest; $\bar{X}$ is the mean of $X$; and $W(i, j)$ is the spatial weight between unit $i$ and $j$ that measures the spatial distance or connection between the two units. $W(i, j)=1$ if unit $i$ and unit $j$ are adjacent, and zero otherwise.

By construction, the value of Moran's $I$ is between -1 and 1. A positive Moran's $I$ (i.e., $I>0)$ indicates that the changed points of water area have a positive spatial correlation and a tendency for spatial objects to cluster or agglomerate. When $I<0$, the changed points of water area have a negative spatial correlation and a tendency for objects to disperse spatially. When $I=0$, the changed points of water area remain in a situation in which spatial objects are distributed randomly. Moran's I measures the overall intensity and concentration of water area changes based on locations and values of individual water area changes within the area. This approach is therefore a global measurement of negative or positive water changes over time.

We also conduct the analysis with a visual examination of water area changes based on 3D-KDS to verify the results of Moran's $I$ estimation. 3D-KDS is a density surface derived from the location of a set of points using a predetermined search radius (or bandwidth) and kernel function. This methodology is effective in dealing with the spatial and temporal dimensions of water area change patterns while avoiding the interpretative complexity of multivariate pattern generalization or recognition methods (Kwan, 2000). A 3D visualization of water area changes can be realized based on the determination of a search radius, baseline height, and kernel density function, as defined in the following equations (Cressie, 1993): 
Search Radius $=0.9 \times \min \left(S D, \sqrt{\frac{1}{\ln (2)}} \times D_{m}\right) \times n^{-0.2}$,

$\lambda_{h}(\boldsymbol{x})=\frac{1}{\delta_{h}(x)} \sum_{i=1}^{n} \frac{w_{i}}{h^{2}} k\left(\frac{x-x_{i}}{h}\right), \quad \boldsymbol{x} \in \boldsymbol{R}$,

$$
k(x)=\left\{\begin{array}{cl}
3 \pi^{-1}\left(1-x^{T} x\right)^{2} & \text { if } x^{T} x \leq 1 \\
0 & \text { otherwise }
\end{array},\right.
$$

where SD is the standard distance, $\mathrm{D}_{\mathrm{m}}$ is the median distance, $\mathrm{n}$ is the number of points, $\mathfrak{R}$ represents the study area, $\boldsymbol{x}$ represents a general location in $\mathfrak{R}, \boldsymbol{x}_{1}, \boldsymbol{x}_{2} \ldots \boldsymbol{x}_{n}$ are the locations of water area change, $\lambda(\boldsymbol{x})$ represents the density at $\boldsymbol{x}$, and $k($.$) is the kernel$ function. Parameter $h>0$ is the bandwidth that determines the amount of smoothing. $w_{i}$ is a weighing factor, and $\delta_{h}(\boldsymbol{x})$ is an edge correction factor.

We develop a policy scoring system based on the characteristics of land use policies in China to quantify the various land use policies. Relevant land use policies are classified into regional-development (RD), environmental-protection (EP), and food-security (FS) land use policies. Within each category, the Delphi method is applied to obtain the raw scores of these policies, from which the mean score of each policy is calculated. Considering that different policies are implemented at different points of time, a cumulative score for each year is calculated by summing up the average score of all policies applicable to that year. Accumulation scores of different policies (i.e., RD, EP, and FS) are combined with Moran's I estimates and used to estimate Equation (1). Without losing any generality, Equation (1) can be estimated by using the OLS method, as follows:

$I_{i}=\beta_{0}+\beta_{1} R D+\beta_{2} E P+\beta_{3} F S+\sum_{k=1}^{K} \alpha_{k} C_{k}+\varepsilon$,

$i \in\{P, N\}$,

where $C_{k}, \mathrm{k}=1, \ldots \mathrm{K}$, is $\mathrm{kth}$ climate change variable included in $\boldsymbol{C}$, as defined in Equation (1). $\beta_{1}, \beta_{2}$, and $\beta_{3}$ determine the impact of RD, EP, and FS land use policies, respectively. Multicollinearity will be an issue for the estimation of Equation (6) because the three land use policy variables are highly correlated. The coefficient estimates of $\beta_{1}, \beta_{2}$, and $\beta_{3}$ will be biased, and the corresponding t test will not be 
reliable. To resolve this issue, a simple orthogonalization procedure developed by Clayton and MacKinnon (2001) can be adopted as described below. This approach has numerous applications in property research areas (Clayton and MacKinnon, 2003; Lizieri, 2013).

To obtain land use policy variables that are not correlated with one another, EP and $F S$ are regressed on the other two policy variables, as follows.

$$
\begin{aligned}
& E P=\gamma_{0}+\gamma_{1} R D+\gamma_{2} F S+v \\
& F S=\theta_{0}+\theta_{1} R D+\theta_{2} E P+\xi
\end{aligned}
$$

By construction, $v$ and $\xi$ are not correlated with the independent variables included in the corresponding regression models. Therefore, the estimate of $v$ can be used as pure $E P$ factor because it is not correlated with both $R D$ and $F S$. Similarly, the estimate of $\xi$ can be used as pure $F S$ factor in Equation (6). Therefore, Equation (6) can be rewritten as follows:

$I_{i}=\beta_{0}+\beta_{1} R D+\beta_{2} E P^{*}+\beta_{3} F S^{*}+\sum_{k=1}^{K} \alpha_{k} C_{k}+\varepsilon$,

$i \in\{P, N\}$,

where $E P^{*}$ is the residual from Equation (7) and $F S^{*}$ is the residual from Equation (8). Given that the three policy variables in Equation (9) are not correlated with one another, the coefficient estimates of $\beta_{1}, \beta_{2}$, and $\beta_{3}$ are the net effect of each type of land use policy on water area changes. Standardized coefficient estimates from Equation (9) can be used to determine the relative importance of each type of policy on either negative or positive water area changes.

In summary, we use Moran's $I$ as a global measurement of water area changes and develop a policy score system to quantify the land use policies in effect during the study period. Moran's I estimates are combined with 3D-KDS to analyze water area changes visually and numerically. Moran's I estimates are then combined with policy scores in an orthogonalized OLS regression model to obtain standardized coefficient estimates, 
which can be used to evaluate the effectiveness of land use policies on hydrological environment protection. The methodological framework of this paper is illustrated in Figure 1.

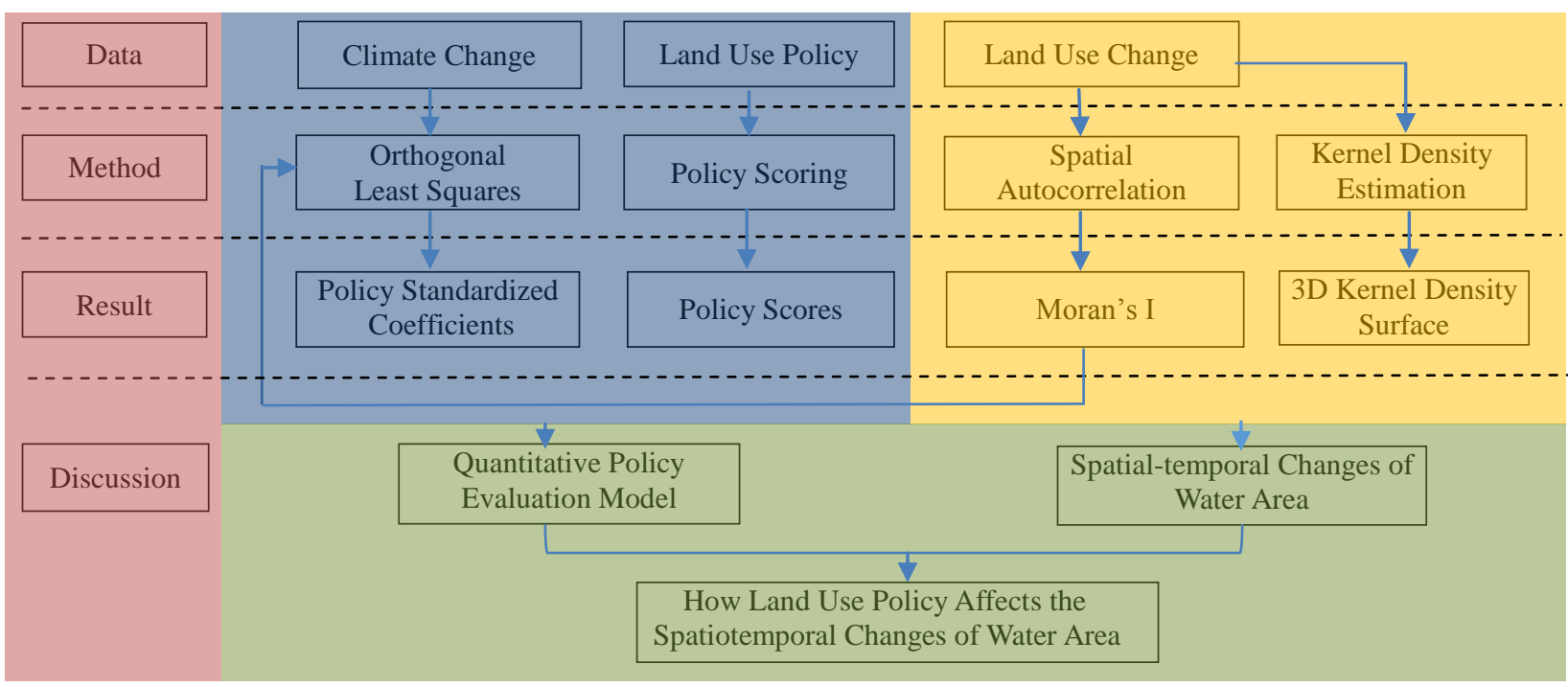

Figure 1 Flowchart of the methodology

\section{Empirical Implementation}

\subsection{Study Area}

We choose Ejina, Inner Mongolia, China as the study area because land uses in this region are subject to changes of both government policies and natural environment. Arid regions in northwest China are facing increasingly severe water scarcity due to drought and desertification. Facing the challenges, both central and local governments rolled out policies and regulations to protect the sustainable use of water resources in these regions (Liu and Yang, 2012; Yang et al., 2013). China has a leasehold property right system with a wide array of fast-changing land use policies at work. In China urban lands are owned by the state; arable lands are jointly owned by rural collectives (i.e., groups of rural residents in the same village). Land transactions are exchanges of leases for land use rights with terms ranging from 40 years for commercial lands to 70 years for residential uses. Central government controls the overall supply of land use rights at national level, whilst land use rights are contracted out by local governments through negotiations, tenders, and auctions. Under this system, land use policies have significant 
influence on both land uses and water resources management. This is particularly true in Ejina, one of the arid regions that have been affected by both natural environment and land use policies. It provides a natural setting to test our model.

Ejina is located in the lower catchment area of the Heihe River Basin and has a total area of 114.6 thousand $\mathrm{km}^{2}$. It is surrounded by the Qilian Mountains in the south and the Badain Jaran Desert in the east. The downstream waters of the Heihe, East, and West Rivers serve as important water sources that maintain the Ejina Oasis. Urban development and over-utilization of water resource in Ejina area have led to desertification of land, degeneration of vegetation, and an overall deterioration in the ecological environment. These phenomena have had a serious effect on the downstream desert oasis, restricted the economic development in the river basin, and hindered sustainable development of the area. The ecological environment of Ejina has worsened; water flows have been blocked, the terminal lake has vanished, the groundwater table has lowered, the vegetation has degenerated, the natural oasis has withered, desertification has developed rapidly, and sand storms have been aggravated. 


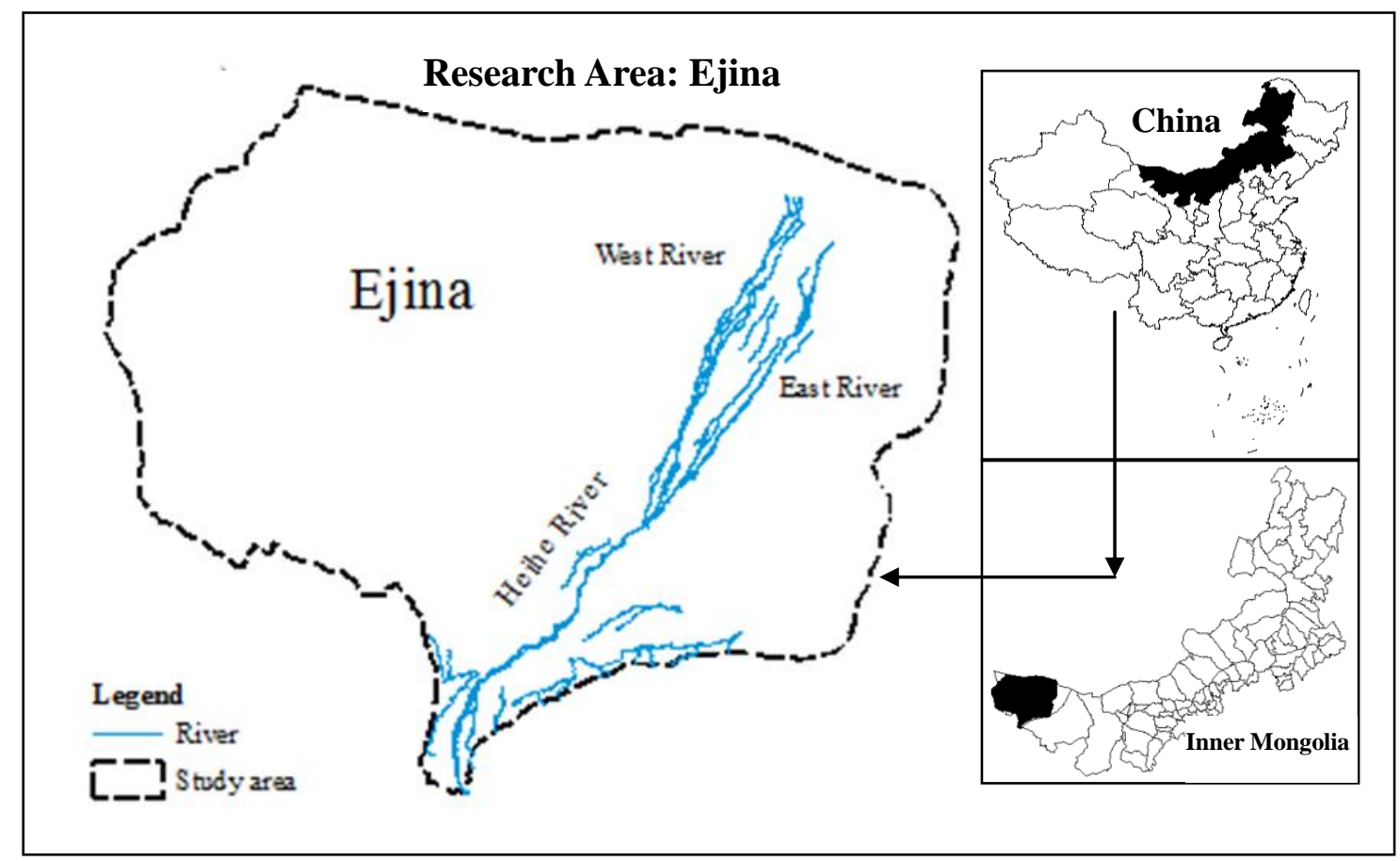

Figure 2 Map of the study area

\subsection{Land Use Policy Variables}

National land use policy and land tenure reform documents were collected from the Ministry of Land and Resources of China. Regional land use policies and RD planning documents were obtained from local government departments, such as the Land Resource Bureau, Environmental Protection Bureau, and Agricultural Bureau (Long, 2014). Delphi method was used to select the most important land use policies in each of the three policy categories. The results are shown in Table 2.

Using the Delphi method, we invited experts to give scores on the importance of each policy on negative and positive water area changes. The Delphi analysis was carried out through the following steps: (1) objectives assessment, (2) experts invitation, (3) questionnaire distribution, (4) policy evaluation, and (5) score calculation. The Delphi study was carefully conducted to ameliorate potential anchoring effect and confirmation bias (Chapman and Johnson, 2003; Jacowitz and Kahneman, 1995; Kahneman and Tversky, 1979; Strack and Mussweilert, 1997). To circumvent anchor effect, we include researchers from different research institutes and local leaders from Ejina. By doing so, even if experts inevitably anchor their opinions on own experience and expertise, the 
variety of expert background ensures the assessment won't be biased toward any particular aspects or areas. To reduce confirmation bias, we took measurement to ensure questionnaires are completed independently. All questionnaires were completed and returned within one month, which also helps to reduce the chance of experts talking to each other.

Accumulated scores of different policies (i.e., RD, EP, and FS) for each year were calculated based on the average scores and used in the final step of our analysis. The descriptive statistics of accumulated policy scores can be found in Table 3 .

Table 2 List of Selected Land Use Policy

\begin{tabular}{|c|c|c|c|}
\hline Type & No. & Time & Land Use Policy \\
\hline $\mathrm{RD}$ & $\begin{array}{l}1 \\
2 \\
3 \\
4 \\
5 \\
6 \\
7 \\
8 \\
9 \\
10\end{array}$ & $\begin{array}{l}\text { 1966-now } \\
1986-\text { now } \\
1994-\text { now } \\
2000 \text {-now } \\
1962-1983 \\
2006-2020 \\
1985-\text { now } \\
1986-1995 \\
1996-2005 \\
1996-2010\end{array}$ & $\begin{array}{l}\text { Nationalization Plan of Urban Land } \\
\text { Land Administration Law of China } \\
\text { Urban Property Administration Law of China } \\
\text { Western Development Plan in China } \\
\text { Regulations of People's Commune of Rural Area } \\
\text { Outline of the National Overall Land Use Plans } \\
\text { Unified Development and General Construction of City } \\
\text { Ninth Five-year Land Development Planning of Ejina } \\
\text { Sustainable Development Plan of the Ejina Oasis } \\
\text { Overall Land Use Plans of Ejina }\end{array}$ \\
\hline $\mathrm{EP}$ & $\begin{array}{l}1 \\
2 \\
3 \\
4 \\
5 \\
6 \\
7 \\
8\end{array}$ & $\begin{array}{l}\text { 1973-now } \\
2000 \text {-now } \\
2008 \text {-now } \\
1996-\text { now } \\
1998 \text {-now } \\
1986-1995 \\
2001-2005 \\
2006-2010\end{array}$ & $\begin{array}{l}\text { Intensive Land Use in the Process of Capital Construction } \\
\text { Plan of Converting Grain Plots back to Forestry, Grass, and Water Areas } \\
\text { Plan of Promoting the Economical and Intensive Utilization of Land } \\
\text { National Overall Land Use Plans } \\
\text { Regulations on the Implementation of Land Administration Law of China } \\
\text { Land Remediation Plan of Ejina } \\
\text { Tenth Five-year Land Reclamation plan of Ejina } \\
\text { Eleventh Five-year Land Reclamation Plan of Ejina }\end{array}$ \\
\hline FS & $\begin{array}{l}1 \\
2 \\
3 \\
4 \\
5 \\
6 \\
7 \\
8 \\
9 \\
10\end{array}$ & $\begin{array}{l}\text { 1994-now } \\
1997-\text { now } \\
2003 \text {-now } \\
2006-\text {-now } \\
1979-1983 \\
1979-2011 \\
1982 \text {-now } \\
1998 \text {-now } \\
\text { 2001-now } \\
\text { 2005-now }\end{array}$ & $\begin{array}{l}\text { Regulations on the Protection of Basic Farmland } \\
\text { Land Management and Protection Plan of Arable Land } \\
\text { Notification of the Implementation of Strict Protection of Arable Land } \\
\text { Proposal of Eighteen Million Acres of Arable Land Red Line } \\
\text { Marginal Land Development of People's Commune of Rural Area } \\
\text { Household Contract Responsibility System } \\
\text { Agricultural Development Projects of Ejina } \\
\text { Prohibit Non-agricultural Construction Projects Occupying Farmland } \\
\text { Responsibility Assessment of Farmland Protection Plan on City Level } \\
\text { Suggestions for Further Improving the Basic Farmland Protection }\end{array}$ \\
\hline
\end{tabular}

\subsection{Land Use Change Data}

Multisource land use datasets were acquired to determine the spatiotemporal changes in the Ejina Oasis from 1962 to 2012. The land use datasets include a topographic map of 1:100,000 produced in 1962, Landsat MSS from 1972, Landsat TM images from 1982, 
and ETM+ from 1992, 2002, and 2012. These data were selected in either summer or autumn because these are the best times to study the oasis. Other maps include land use maps at a scale of 1:100,000 of 1986 and 2010, which were provided by the Heihe Plan Science Data Center of the National Natural Science Foundation of China. With reference to topographic data, geometric corrections and mosaic of the satellite images were implemented using ERDAS 9.3 by following the approach in Zhou et al. (2010). Spectral remote sensing data and textural characteristics were considered based on the characteristics of drought area. Topological relations and attribute data corresponding to the graphic data were established based on the computer-aided interpretation of remote sensing images.

\subsection{Control Variables}

\subsubsection{Water Management Policy}

We considered six important water management policies issued by the Ministry of Water Resources of China (MWR hereafter) and the State Council of China (see Table 3). The effect of water management policy is capture by variable WMP as defined below.

$W M P=\sum_{i=1}^{6} w m p_{i} T_{i}$

In Equation (10), $w m p_{i}$ equals one for policies with direct influences on water area change in Ejina, and $w m p_{i}$ takes a value of 0.5 for policies with indirect effects. More specifically, the first three water policies in Table 3 are specific to the Heihe River in Ejina region. Therefore their effects are direct, and the corresponding water management policy variable $w m p_{i}$ equals one. The value of $w m p_{i}$ for the remaining three water management policies is 0.5 , as these are national level policies with indirect effect on the study area. $T_{i}$ is a time dummy variable to capture the timing of the water management policy. $T_{i}$ equals one in and after the year of implementation of the $i$ th water management policy, and equals zero otherwise. Therefore, WMP is a weighted average of six water management policies, taking into account both the importance and the timing of each policy. The construction of WMP variable is based on a similar approach adopted in Zheng (2014). Descriptive statistics of WMP are given in Table 4. 
Table 3 Water Management Policy

\begin{tabular}{clccc}
\hline No & \multicolumn{1}{c}{ Water Management Policy } & Time & Level & Issued by \\
\hline 1 & $\begin{array}{l}\text { Water Environment Protection Plan in the Lower Reach } \\
\text { of the Hei River }\end{array}$ & 1984-now & Local & MWR \\
2 & Remediation Planning of the Heihe River Basin & 2001-now & Local & MWR \\
3 & Heihe Water Allocation Plan & $2009-$ now & Local & MWR \\
4 & Water Law of the People's Republic of China & 2002-now & National & MWR \\
5 & Law of the People's Republic of China on Water and Soil & 2010-now & National & MWR \\
& $\begin{array}{l}\text { Conservation } \\
6\end{array}$ & & & Segulations on Land Requisition Compensation and \\
& $\begin{array}{l}\text { Resettlement for Large and Medium Sized Water } \\
\text { Conservancy and Hydropower Projects }\end{array}$ & & National & Council \\
\hline
\end{tabular}

\subsubsection{Climate Change Data}

Daily precipitation and temperature in the past 50 years were collected to calculate the annual precipitation and temperature levels. Because of the lack of actual annual evapotranspiration data for the study area, we derived the evapotranspiration data by using a modified Penman-Monteith model, which is the global standard for estimating evapotranspiration used by the United Nations Food and Agriculture Organization ${ }^{1}$. All observed daily meteorological data were provided by the National Meteorological Information Center of China. Descriptive statistics of the climate change variables are given in Table 4.

\footnotetext{
${ }^{1}$ http://www.fao.org/nr/water/eto.html.
} 
Table 4 Descriptive statistics

\begin{tabular}{|c|c|c|c|c|c|c|}
\hline Variable & Definition & Mean & Median & Max. & Min. & Std. Dev. \\
\hline \multirow{3}{*}{$\mathrm{X}_{1}$} & Accumulated Score of RD & & & & & \\
\hline & - for positive changes & 280.35 & 283 & 526 & 62 & 165.25 \\
\hline & - for negative changes & 217.49 & 149 & 624 & 0 & 214.55 \\
\hline \multirow[t]{3}{*}{$\mathrm{X}_{2}$} & Accumulated Score of EP & & & & & \\
\hline & - for positive changes & 133.29 & 98 & 375 & 0 & 122.68 \\
\hline & - for negative changes & 283.14 & 293 & 537 & 63 & 170.06 \\
\hline \multirow[t]{3}{*}{$\mathrm{X}_{3}$} & Accumulated Score of FS & & & & & \\
\hline & - for positive changes & 145.61 & 91 & 432 & 0 & 152.72 \\
\hline & - for negative changes & 165.76 & 125 & 490 & 0 & 161.56 \\
\hline $\mathrm{X}_{4}$ & Water Management Policy & 1.09 & 1 & 4.5 & 0 & 1.34 \\
\hline $\mathrm{X}_{6}$ & $\begin{array}{l}\text { Annual Average } \\
\text { Precipitation (mm) }\end{array}$ & 34.99 & 28.90 & 101.00 & 7.00 & 19.69 \\
\hline $\mathrm{X}_{6}$ & $\begin{array}{l}\text { Annual Average } \\
\text { Temperature }\left({ }^{\circ} \mathrm{C}\right)\end{array}$ & 9.02 & 9.07 & 10.64 & 6.48 & 0.93 \\
\hline $\mathrm{X}_{7}$ & $\begin{array}{l}\text { Annual Average Potential } \\
\text { Evapotranspiration (mm) }\end{array}$ & 1127.26 & 1114.62 & 1341.50 & 972.60 & 97.14 \\
\hline
\end{tabular}

\section{Spatiotemporal Changes in the Water Area}

In this study, we divided the data into five 10-year sub-periods as 1962-1972, 1972-1982, 1982-1992, 1992-2002, and 2002-2012 to facilitate the analysis of water area changes over time. The analysis of the spatiotemporal changes in the water areas over these five sub-periods was based on 3D-KDS patterns and Moran's I coefficients as global measurement of the water area change concentration.

The ArcGIS built-in function was used to generate search radius $(30,000 \mathrm{~km})$ automatically and generate 3D-KDS, as suggested by Kwan (2000). A non-parametric kernel estimation method was used in the kernel density estimation (Bailey and Gatrell, 1995; Silverman, 1986). The quartic kernel function described in Silverman (1986) was used to generate the KDS for each sub-period. $\lambda(\boldsymbol{x})$ was chosen for the baseline height, and every KDS computed with 1,000 m pixel resolution was displayed in ArcScene for $3 \mathrm{D}$ visualization. A total of $10 \mathrm{KDSs}$ were generated, among which, five were for negative changes and five for positive changes. The surfaces are given in Figure 3. A summary of the spatial trend (i.e., the direction of change in patterns) and peak locations are given in Table 4 for negative and positive water area changes in each sub-period. 
The spatial characteristics were further validated by calculating Moran's I coefficients in the five time periods to explore conversions between different land use types and water areas through the spatial autocorrelation method. The results of negative and positive changes in the water area are summarized in Table 5.

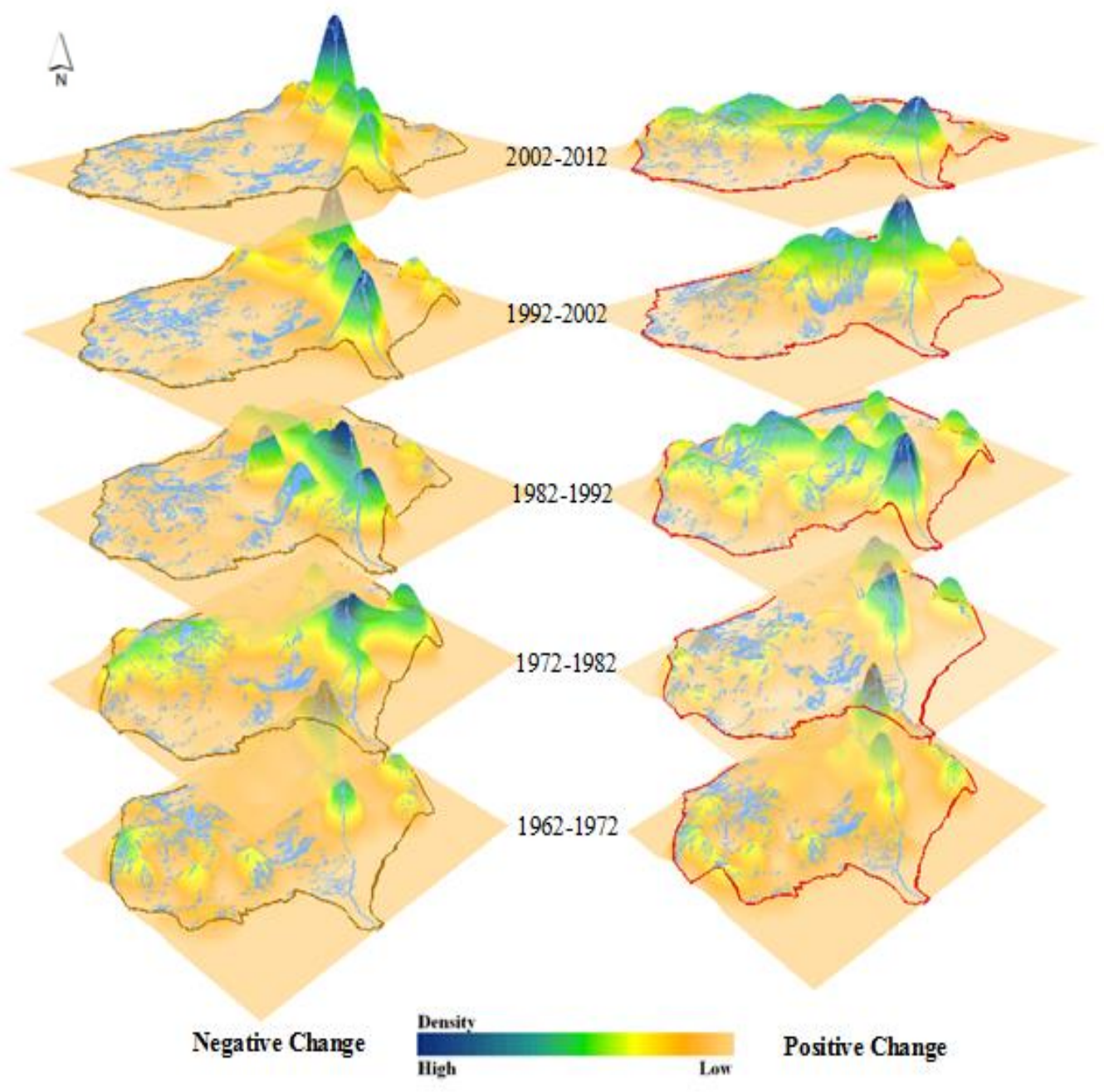

Figure 3 3D-KDS patterns of changes in the water area (1962-2012) 
Table 5 Summary of 3D-KDS patterns and Moran's I estimates

\begin{tabular}{|c|c|c|c|c|c|c|}
\hline \multirow[b]{2}{*}{$\begin{array}{l}\text { Time } \\
\text { Period }\end{array}$} & \multicolumn{3}{|c|}{ Negative Changes } & \multicolumn{3}{|c|}{ Positive Changes } \\
\hline & $\begin{array}{c}\text { Spatial } \\
\text { Trend } \\
(1)\end{array}$ & $\begin{array}{c}\text { Peak } \\
\text { Locations } \\
(2)\end{array}$ & $\begin{array}{c}\text { Moran's I } \\
\text { (3) }\end{array}$ & $\begin{array}{l}\text { Spatial } \\
\text { Trend } \\
(4)\end{array}$ & $\begin{array}{c}\text { Peak } \\
\text { Locations } \\
(5)\end{array}$ & $\begin{array}{c}\text { Moran's I } \\
\text { (6) }\end{array}$ \\
\hline 1962-1972 & not visible & original & 0.38 & $\begin{array}{c}\text { north-east } \\
\text { and south-west }\end{array}$ & original & 0.39 \\
\hline $1972-1982$ & not visible & different & 0.41 & $\begin{array}{c}\text { north-east } \\
\text { and south-west }\end{array}$ & similar & 0.43 \\
\hline 1982-1992 & $\begin{array}{l}\text { north-east } \\
\text { and south-west }\end{array}$ & different & 0.50 & not visible & different & 0.42 \\
\hline 1992-2002 & $\begin{array}{c}\text { north-east } \\
\text { and south-west }\end{array}$ & similar & 0.52 & $\begin{array}{c}\text { north-west } \\
\text { and south-east }\end{array}$ & similar & 0.49 \\
\hline 2002-2012 & $\begin{array}{c}\text { north-east } \\
\text { and south-west }\end{array}$ & similar & 0.62 & $\begin{array}{c}\text { north-west and } \\
\text { south-east }\end{array}$ & different & 0.47 \\
\hline
\end{tabular}

\subsection{Negative Changes in the Water Area}

Figure 3 shows the five 3D-KDSs on the left panel, which displayed negative changes in the water area over the five sub-periods. The patterns generally suggested that the concentration of negative water area changes intensified over time.

In the first two sub-periods of 1962-1972 and 1972-1982, no clear patterns of negative changes were visible, indicating that negative water changes were distributed evenly during the early sub-periods. The peaks of these two sub-periods were located along the West River, where human activity was concentrated primarily. In the sub-period of 1982-1992, surfaces of negative changes suggested that the concentration of negative changes in the water area followed the northeast and southwest directions in general. Distinctive peaks were visible in the figure, indicating a high concentration of water area conversions into other land use types. The peaks were located near the three main rivers (i.e., Heihe, East, and West Rivers). This pattern persisted in the sub-periods of 1992-2002 and 2002-2012. Although the height of the peaks changed over the two sub-periods, the location of the peaks and overall patterns remained the same since 1992. Peaks of negative water area changes were all found near the three main rivers, and the kernel density patterns followed the northeast and southwest directions. Hence, human activities were closely connected to negative water area changes in the study area.

We also examined Moran's I coefficient in each of the sub-periods to explore the spatiotemporal pattern of negative changes in the water area, as given in column (3) in 
Table 5. The values were positive with a strong upward trend over time. Moran's I coefficients in the sub-periods of 1982-1992 and 2002-2012 exhibited a slight decrease over the previous sub-periods. These two small dips did not change the overall trajectory in the concentration of positive water area changes. Steady creation or conversion of water areas from other types of land use had been observed in the past 50 years. The results were consistent with 3D-KDS patterns.

In general, the spatial distribution of the negative changed points (i.e., places where water areas were converted to other types of land use) agglomerated gradually and followed a general northeast-to-southwest pattern. The sub-periods of 1982-1992 and 2002-1012 witnessed intensive negative changes in the water area. The density peaks lied mainly in the eastern part of the study area, especially near the East, West, and Heihe Rivers, where human activities concentrated. Human activities exacerbated negative water area changes.

\subsection{Positive Changes in the Water Area}

The patterns of positive changes in the water area over the five sub-periods can be seen in the five 3D-KDSs on the right panel of Figure 3. Similar to the findings in Subsection 4.1, the patterns suggested that the concentration of negative water area changes intensified over time, although the concentration level became weaker.

The pattern and density peaks did not change much in the sub-periods of 1962-1972 and 1972-1982. A concentration of positive water area changes was visible, which followed northeast and southwest patterns. A subtle shift of peak locations to the north occurred in the sub-period of 1972-1982. The pattern changed notably in the sub-period of 1982-1992, and a different distribution of positive water area changes evolved. Points were evenly distributed across the county; new peaks evolved and located further to the north and west. Conversion from other types of land to water areas began to concentrate in the areas far from the main rivers. As to the 1992-2002 sub-period, peaks changed location and height with a visible concentration in the northeast direction, and peaks were located close to the main river system again. In the most recent sub-period of 2002-2012, the concentration of positive water area changes had reduced, with a small peak located near the main river. The rest of the water area conversions were scattered in the entire region, with the pattern changing distinctively from previous 
sub-periods.

Moran's I coefficient, as given in Table 5, showed positive points correlated in space and had a tendency to agglomerate at the regional level. However, the trend was not as strong as in negative changes. The clustering patterns had some fluctuations, which were not identified in the trend of negative changes. The maximum value of Moran's I coefficient appeared in the sub-period of 1992-2002 and decreased slightly in the following period. Overall, the results of Moran's $I$ also coincided with the 3D kernel density results. Although several differences could be observed among the five sub-periods of positive changes, a clustering status was also observed in the entire region.

The five different patterns of 3D kernel density reveal the largest difference among the five time periods in the positive changes of water area. The spatial distribution of positive points shifted from northeast to northwest, and the clustering patterns varied during the five sub-periods. Peaks in intensity did not coincide with areas but were concentrated mainly in areas of human activity located in the eastern part of the study area near the East, West, and Heihe Rivers.

\subsection{Comparison between Negative and Positive Changes}

In the first two sub-periods, the peaks of the two types of water area changes were located at almost the same space. From the sub-period of 1972-1982, negative changes were concentrated along the main rivers, whereas positive changes began to appear in the northwest direction. This pattern continued for the two subsequent sub-periods of 1992-2002 and 2002-2012. In the final sub-period, 3D-KDS patterns of changes in the water area indicated distinct differences between negative and positive changes. The prominent density peaks of negative changes in water area were located near the area where human activities concentrated (i.e., the three main rivers). On the contrary, density peaks were small for positive water area changes and lay in the northwest region of the study area, which is far away from the main rivers. Positive points were more evenly distributed compared with the strong clustering patterns of negative changes. Evidence suggests that negative changes in water area were more associated with human activities than positive changes in the recent years. 


\section{Effects of Land Use Policies on Spatiotemporal Changes in the}

\section{Water Area}

The analysis in Section 4 suggests a link between human activities and water area changes. We explore along this direction further by analyzing the impact of land use policy on water area changes in this section. Equation (9) is estimated by using the variables defined in Table 3.

$I_{i}=\beta_{0}+\beta_{1} X_{1}+\beta_{2} X_{2}+\beta_{3} X_{3}+\beta_{4} X_{4}+\beta_{5} X_{5}+\beta_{6} X_{6}+\beta_{7} X_{7}+\varepsilon$

$i \in\{P, N\}$

Considering that multicollinearity is potentially serious in our data set, we run a correlation analysis among the seven independent variables. The results are listed in Table 6. Except for precipitation (i.e., $X_{5}$ ), all other six variables are significantly correlated at the $1 \%$ level. A standard OLS estimation (Labeled as Model 1 in Tables 8 and 9) that utilizes Equation (9) also confirms this finding because most of the VIFs obtained are higher than 20. Subsequently, many independent variables are statistically insignificant due to inflated variances. Moreover, unit root test reveals that these six variables are non-stationary (see Table 7). Therefore, we orthogonalize the other six variables (i.e., $X_{1}, X_{2}, X_{3}, X_{4}, X_{6}$, and $X_{7}$ ) by using the method described in Section 2. Both unstandardized and standardized coefficient estimates from the orthogonalized OLS models are obtained for positive and negative water area changes. The results are labeled as Model 2 in Tables 7 and 8.

The orthogonalized models show much improvement over standard OLS models. First, the orthogonalization process effectively removed the common trend in these variables. The transformed variables are now stationary (see the unit root test results in Table 7), which meets the requirement in linear regression analysis. There is no risk of spurious regression. Second, the orthogonalized models provide a considerable number of economically and statistically significant coefficient estimates (highlighted in bold face and italic). Most of the land use policy variables are not significant at the $10 \%$ level in both standard OLS models. Nevertheless, in the corresponding orthogonalized models, 
these variables are all significant with expected signs. The orthogonalization process adopted in this study only changes the coefficient estimates, without affecting the overall model fitting statistics, such as R squares and F test statistics. As shown on the bottom panel in Tables 6 and 7, all models have satisfactory R squares and F test results. The models fit the data well.

However, both Model 1 and Mode 2 fail to pass the RESET test, the DW test, and the White heteroscedasticity tests. This suggests that we should check nonlinear relationship and moderating effects from the climate factors. We subsequently estimated an augmented orthogonalized model by including squared terms of all variables, as well as interaction terms between the four policy variables and the three climate variables (labeled as Model 3 in Tables 8 and 9). Both models pass the RESET test, thereby indicating that they are free of model misspecification errors. The White heteroscedasticity test result for the positive water change model is marginal. The negative water change models fail the DW autocorrelation test. But these violations of OLS assumption does not bias coefficient estimates. The heteroscedasticity and autocorrelation consistent standard errors are used to calculate p-values in Tables 8 and 9 to address these issues.

The augmented orthogonalized models provide good coefficient estimates and pass relevant diagnostic tests. The discussion in the rest of this section is based on the standardized coefficients from Model 3 in Tables 8 and 9. The standardized coefficient estimates are obtained by computing $\mathrm{Z}$ scores for each of the dependent and independent variables. The standardized variables are used in the regression analysis. Such an approach removes the unit from all variables, making it possible to compare the impact of independent variables directly.

The following conclusions can be drawn from the standardized coefficient estimates from the augmented orthogonalized OLS models. First, land use policy and water management policy have greater impact on water area changes than natural environment factors, such as temperature and precipitation. In both negative and positive change models, the standardized coefficient estimates of $X_{1}$ to $X_{4}$ are more than twice those of $X_{5}$ to $X_{7}$. Human activities in general have a significant impact on hydrological environment changes in our study area. 
Second, coefficient estimates of land use policy indicators are all positive and significant in all models. Therefore, land use policy can considerably influence both types of changes in our study area. Although water management policy can affect both positive and negative water changes as well, it is less effective than land use policy. This is suggested by the smaller coefficient estimates of $X_{4}$ in comparison with the coefficient estimates of $X_{1}$ to $X_{3}$. As all lands are owned by the state in China, the distribution and management of land and other natural resources (including water) are centrally controlled by the Ministry of Land and Resources of China (MLR). Policies issued by MLR are often used as guidelines by other government institutions, such as the Ministry of Water Resources. Therefore it is not surprising to find that land use policies issued by MLR have greater influence on water area changes than water management policies. This finding supports our notion that studying the effect of land use policy on water area changes is very important in China.

Third, the effect of land use policy on the two types of water area change is asymmetric. More specifically, most land use policy variables have large coefficient loadings in the negative change model. Hence, the land use policy in our study area is effective in causing concentration or agglomeration of negative water area changes. Most of the squared terms of land use policy in Table 8 are significant and positive. This indicates that the effect of land use policy on positive water area change increases exponentially as policy score improves. Therefore technically the effect on positive water change can equal or even surpass the effect on negative water change for very important land use policy (as indicated by a large subjective score by experts). We also found that climate factors can affect the effectiveness of land use policy on positive water changes only. For example, the negative coefficient estimates of the interaction terms between precipitation and land use policy in Table 8 suggest that when precipitation is high land use policy is less effective on positive water change. One of many possible reasons is that when precipitation is high local government is more confident about increasing water areas, and subsequently more relaxed in implementing the policies.

Our empirical results suggest that water area changes in Ejina have been significantly affected by the 28 land use policies implemented between 1962 and 2012. The net effect is greater than the influence from water management policy and climate change. Hence, 
local governments should be aware of the impact from human activities driven or affected by land use policies. This pattern is consistent in both the negative and positive water area change models. It is also important to separate the effect of land use policy in inducing the agglomeration of positive and negative water area changes, as our findings suggest the impact on these two types of water area changes is asymmetry.

The statistical analysis in this section largely confirms the 3D-KDS results in Section 4. In the first two sub-periods between 1962 and 1982, the government did not allot much attention to land management other than wasteland production. Therefore, the implementation of land use policy on negative changes in water area is not obvious in the 3D-KDS maps. It was not until the implementation of "Land Administration Law of China" (1986 version) along with the Ninth Five-year Land Development Plan of Ejina, that the scientific concept had played a role in managing land use and in guiding land development. In this plan, the location and size of land supply before 2010 are specified and used to guide land uses in Ejina. With the increasing demand on water resources in this arid region, urban areas had developed mainly around the surroundings of the rivers. Accordingly, the peaks of kernel density maps of negative water area changes were also located along the rivers.

Similarly, owing to the lack of awareness in land use policies between 1962 and 1982, no visible patterns of positive water area changes can be identified in the 3D-KDS maps. However, environmental problems were exacerbated in the sub-period of 1982-1992 because of the over-exploitation of land and water resources; rivers and lakes in the study area dried up, and sandstorms occurred frequently. Local government acted proactively by implementing the "Land Remediation Plan of Ejina" in 1986, this plan, coupled with the "Remediation Planning of the Heihe River Basin," which came into effect in 2001, promoted conversions from arable land, constructed land, and grass land to water areas. The effects of these policies manifested as changes in peak locations and wide distribution of positive water area changes in the recent sub-periods.

Our statistical model accurately captures the increasing influences of government intervention on water area changes by reporting positive coefficient estimates for all policy indicators. The statistical model also separates the net effect of each type of land use policy (e.g., EP policies have the greatest impact on both positive and negative 
water areas changes). This model helps disentangle the patterns identified in 3D-KDS maps and provides useful insights for policy makers to assist in the monitoring of the implementation of existing policies and in designing new ones. From the theoretical perspective, our analysis shows that land use policies have greater influence on water area changes than water management policies and climate change factors. This highlights the importance of considering land use policies in the study of water resources management. Further research could be conducted to verify these findings in broader context, such as the management of other types of natural resources.

\section{Conclusion}

Land use policies are often designed with the intention of striking a balance between man and the natural environment and between economic development and ecological sustainability. In reality, the implementation of land use policies is affected by various economic, social, political, and environmental changes. Consequently, the outcomes of these policies may not be as intended, and the impact of land policies on environment can be either positive or adverse. Hence, monitoring and understanding the effects of land use policies on environmental issues are theoretically and practically important.

In this study, we focus on the impact of land use policy on the changes in an essential natural resource, that of water in an arid area. We developed a model by combining quantitative and qualitative approaches, including Delphi method, Moran's I, 3D-KDS technique, and orthogonalized regression. The model facilitates visual examination of spatiotemporal patterns in water area changes and identification of the net effect of land use policies on water area changes. We test the model by using data from Ejina, an oasis area from Inner Mongolia, China. The results of the combined 3D-KDS and Moran's I coefficient indicate distinctive patterns in negative and positive water area changes. Standardized coefficients from the orthogonalized OLS models helped isolate the net effect of three types of land use policies on negative and positive water area changes. Land use policies had a greater impact on hydrological environment changes than water management policies and climate change factors. Our model is straightforward in implementing appropriate data, and the interpretation of results is not technically demanding. The model outputs can also be utilized to assess the effectiveness of land 
use policies in a particular area. Hence, the model can be helpful in monitoring the implementation of existing policies and the design of new land use policies.

In this paper we considered only surface water area changes due to data constraints. As technology advances, it is possible to obtain geo-coded data on the location and size of groundwater as well. Our model can then be used to analyze and visualize the changes of both surface and groundwater areas. This will aid the monitoring and managing of groundwater resources, which is more challenging than that of surface water resources. More importantly, the findings can be used to understand the relations between the changes of surface water and ground water resources. Ultimately, this will be very helpful for designing land use policies that cater for sustainable water resource management.

\section{Acknowledge}

The authors are indebted to the National Natural Science Fund (41571162) and Advantage Discipline Construction Project of Jiangsu Province. 
Table 6 Correlation Coefficients

\begin{tabular}{|c|c|c|c|c|c|c|c|}
\hline \multicolumn{8}{|c|}{ Panel A: Positive Water Changes } \\
\hline & $X_{1}$ & $X_{2}$ & $X_{3}$ & $X_{4}$ & $X_{5}$ & $X_{6}$ & $X_{7}$ \\
\hline$X_{1}$ & 1 & & & & & & \\
\hline$X_{2}$ & $0.929 *$ & 1 & & & & & \\
\hline$X_{3}$ & $0.910 *$ & $0.969 *$ & 1 & & & & \\
\hline$X_{4}$ & $0.831 *$ & $0.918 *$ & $0.920 *$ & 1 & & & \\
\hline$X_{5}$ & -0.077 & -0.134 & -0.121 & -0.131 & 1 & & \\
\hline$X_{6}$ & $0.769 *$ & $0.730 *$ & $0.733^{*}$ & $0.622 *$ & -0.108 & 1 & \\
\hline$X_{7}$ & $-0.640 *$ & $-0.548 *$ & $-0.597 *$ & $-0.549 *$ & -0.046 & $-0.476^{*}$ & 1 \\
\hline \multicolumn{8}{|c|}{ Panel B: Negative Water Changes } \\
\hline & $X_{1}$ & $X_{2}$ & $X_{3}$ & $X_{4}$ & $X_{5}$ & $X_{6}$ & $X_{7}$ \\
\hline$X_{1}$ & 1 & & & & & & \\
\hline$X_{2}$ & $0.928^{*}$ & 1 & & & & & \\
\hline$X_{3}$ & $0.899 *$ & $0.952 *$ & 1 & & & & \\
\hline$X_{4}$ & $0.840^{*}$ & $0.925^{*}$ & $0.910 *$ & 1 & & & \\
\hline$X_{5}$ & -0.065 & -0.132 & -0.117 & -0.131 & 1 & & \\
\hline$X_{6}$ & $0.767 *$ & $0.729 *$ & $0.734^{*}$ & $0.622 *$ & -0.108 & 1 & \\
\hline$X_{7}$ & $-0.659 *$ & $-0.540^{*}$ & $-0.631 *$ & $-0.549 *$ & -0.046 & $-0.476^{*}$ & 1 \\
\hline
\end{tabular}

Note: $* p<1 \%$ for the null hypothesis of zero correlation.

Table 7 Unit Root Tests

\begin{tabular}{|c|c|c|c|c|}
\hline \multirow[b]{2}{*}{ Variables } & \multicolumn{2}{|c|}{ Original variables } & \multicolumn{2}{|c|}{ Orthogonalized Variables } \\
\hline & Test Statistic & P-value & Test Statistic & $\mathrm{P}$-value \\
\hline \multicolumn{5}{|c|}{ Positive Changes Analysis } \\
\hline$X_{l}(\mathrm{RD})$ & 0.7747 & 0.8776 & -2.5145 & 0.0129 \\
\hline$X_{2}(\mathrm{EP})$ & 1.7093 & 0.9775 & -3.4383 & 0.0009 \\
\hline$X_{3}(\mathrm{FS})$ & 1.5389 & 0.9680 & -3.0629 & 0.0029 \\
\hline$X_{4}(\mathrm{WMP})$ & 2.8261 & 0.9985 & -1.9490 & 0.0498 \\
\hline$X_{5}$ (Precipitation) & -8.0639 & 0.0000 & -- & -- \\
\hline$X_{6}$ (Temperature) & 0.2720 & 0.7607 & -4.8723 & 0.0000 \\
\hline$X_{7}$ (Evaporation) & -0.9318 & 0.3081 & -3.0300 & 0.0032 \\
\hline \multicolumn{5}{|c|}{ Negative Changes Analysis } \\
\hline$X_{l}(\mathrm{RD})$ & 0.9709 & 0.9099 & -2.8759 & 0.0049 \\
\hline$X_{2}(\mathrm{EP})$ & 1.5678 & 0.9698 & -3.6296 & 0.0005 \\
\hline$X_{3}(\mathrm{FS})$ & 1.1869 & 0.9376 & -3.0872 & 0.0027 \\
\hline$X_{4}(\mathrm{WMP})$ & 2.8261 & 0.9985 & -2.1038 & 0.0352 \\
\hline$X_{5}$ (Precipitation) & -8.0639 & 0.0000 & -- & -- \\
\hline$X_{6}$ (Temperature) & 0.2720 & 0.7607 & -4.8818 & 0.0000 \\
\hline$X_{7}$ (Evaporation) & -0.9318 & 0.3081 & -3.4284 & 0.0010 \\
\hline
\end{tabular}

Note: p-values are for the null hypothesis of an unit root (non-stationarity). $X_{5}$ (Precipitation) is not orthogonalized because its low correlation with other variables and I(O) status. 
Table 8 OLS and Orthogonalized OLS Results-Positive Water Changes

\begin{tabular}{|c|c|c|c|c|c|}
\hline \multirow[b]{2}{*}{ Variable } & \multirow{2}{*}{$\begin{array}{c}\text { Model 1: OLS } \\
\text { Unstandardized } \\
\text { Coefficient }\end{array}$} & \multicolumn{2}{|c|}{ Model 2: Orthogonalized OLS } & \multicolumn{2}{|c|}{$\begin{array}{l}\text { Model 3: Augmented } \\
\text { Orthogonalized OLS }\end{array}$} \\
\hline & & $\begin{array}{c}\text { Unstandardized } \\
\text { Coefficient }\end{array}$ & $\begin{array}{c}\text { Standardized } \\
\text { Coefficient }\end{array}$ & $\begin{array}{l}\text { Unstandardized } \\
\text { Coefficient }\end{array}$ & $\begin{array}{r}\text { Standardized } \\
\text { Coefficient }\end{array}$ \\
\hline $\mathrm{C}$ & 0.5270 & 0.4318 & & 0.4178 & \\
\hline$X_{I}(\mathrm{RD})$ & -0.0000004 & 0.0023 & 2.5833 & 0.0021 & 2.3512 \\
\hline$X_{2}(\mathrm{EP})$ & 0.0006 & 0.0077 & 3.9950 & 0.0082 & 4.2072 \\
\hline$X_{3}(\mathrm{FS})$ & -0.0002 & 0.0044 & 3.2709 & 0.0047 & 3.4360 \\
\hline$X_{4}(\mathrm{WMP})$ & -0.0203 & 0.1637 & 1.7003 & 0.1832 & 1.9032 \\
\hline$X_{5}($ Precipitation $)$ & 0.0002 & 0.00002 & 0.0086 & -0.0002 & -0.0730 \\
\hline$X_{6}$ (Temporature) & 0.0100 & 0.0912 & 1.1329 & 0.0593 & 0.7367 \\
\hline$X_{7}$ (Evaporation) & -0.0002 & -0.0006 & -0.9338 & -0.0004 & -0.6317 \\
\hline \multicolumn{6}{|l|}{ Higher order terms } \\
\hline$X_{I} \times X_{I}$ & & & & 0.000004 & 0.2560 \\
\hline$X_{2} \times X_{2}$ & & & & 0.000008 & 0.1144 \\
\hline$X_{3} \times X_{3}$ & & & & 0.000004 & 0.1218 \\
\hline$X_{4} \times X_{4}$ & & & & 0.0290 & 0.1932 \\
\hline$X_{5} \times X_{5}$ & & & & 0.0000004 & 0.0167 \\
\hline$X_{6} \times X_{6}$ & & & & -0.0104 & -0.1482 \\
\hline$X_{7} \times X_{7}$ & & & & 0.000002 & 0.2628 \\
\hline \multicolumn{6}{|c|}{ Moderating Effect from Climate } \\
\hline \multicolumn{6}{|c|}{ Factors } \\
\hline$X_{5} \times X_{I}$ & & & & -0.000009 & -0.3902 \\
\hline$X_{5} \times X_{2}$ & & & & -0.00007 & -1.4370 \\
\hline$X_{5} \times X_{3}$ & & & & -0.00004 & -0.9989 \\
\hline$X_{5} \times X_{4}$ & & & & -0.0020 & -0.7358 \\
\hline$X_{6} \times X_{I}$ & & & & 0.00004 & 0.0279 \\
\hline$X_{6} \times X_{2}$ & & & & -0.0018 & -0.4316 \\
\hline$X_{6} \times X_{3}$ & & & & -0.0012 & -0.3886 \\
\hline$X_{6} \times X_{4}$ & & & & -0.0945 & -0.4108 \\
\hline$X_{7} \times X_{I}$ & & & & -0.000005 & -0.5084 \\
\hline$X_{7} \times X_{2}$ & & & & 0.000002 & 0.1062 \\
\hline$X_{7} \times X_{3}$ & & & & -0.0000006 & -0.0336 \\
\hline$X_{7} \times X_{4}$ & & & & -0.0001 & -0.0826 \\
\hline R-squared & 0.8089 & 0.8089 & & 0.9435 & \\
\hline Adjusted R-squared & 0.7778 & 0.7778 & & 0.8823 & \\
\hline Reset Test P-value & 0.0004 & 0.0004 & & 0.3233 & \\
\hline White Test P-value & 0.0231 & 0.0283 & & 0.0494 & \\
\hline DW Test & 0.8455 & 0.8455 & & 2.4086 & \\
\hline F-statistics (Prob) & $26.0033(<0.01)$ & 26.0033 & $(<0.01)$ & 15.4195 & $(<0.01)$ \\
\hline
\end{tabular}

Note: Coefficient estimates in bold face and italic are significant at the $5 \%$ level. 
Table 9 OLS and Orthogonalized OLS Results-Negative Water Changes

\begin{tabular}{|c|c|c|c|c|c|}
\hline \multirow[b]{2}{*}{ Variable } & \multirow{2}{*}{$\begin{array}{c}\text { Model 1: OLS } \\
\text { Unstandardized } \\
\text { Coefficient }\end{array}$} & \multicolumn{2}{|c|}{ Model 2: Orthogonalized OLS } & \multicolumn{2}{|c|}{$\begin{array}{l}\text { Model 3: Augmented } \\
\text { Orthogonalized OLS }\end{array}$} \\
\hline & & $\begin{array}{c}\text { Unstandardized } \\
\text { Coefficient }\end{array}$ & $\begin{array}{l}\text { Standardized } \\
\text { Coefficient }\end{array}$ & $\begin{array}{l}\text { Unstandardized } \\
\text { Coefficient }\end{array}$ & $\begin{array}{r}\text { Standardized } \\
\text { Coefficient }\end{array}$ \\
\hline $\mathrm{C}$ & 0.6453 & 0.5076 & & 0.5247 & \\
\hline$X_{I}(\mathrm{RD})$ & 0.00004 & 0.0050 & 2.8757 & 0.0049 & 2.8093 \\
\hline$X_{2}(\mathrm{EP})$ & 0.000006 & 0.0119 & 4.3590 & 0.0114 & 4.1686 \\
\hline$X_{3}(\mathrm{FS})$ & 0.00008 & 0.0053 & 3.3996 & 0.0055 & 3.5195 \\
\hline$X_{4}(\mathrm{WMP})$ & 0.0304 & 0.4601 & 2.4884 & 0.4605 & 2.4903 \\
\hline$X_{5}($ Precipitation $)$ & -0.0003 & -0.00068 & -0.1538 & -0.0001 & -0.0311 \\
\hline$X_{6}$ (Temporature) & 0.0048 & 0.1637 & 1.0709 & 0.1504 & 0.9841 \\
\hline$X_{7}$ (Evaporation) & -0.0002 & -0.0016 & -1.1145 & -0.0017 & -1.2516 \\
\hline \multicolumn{6}{|l|}{ Higher order terms } \\
\hline$X_{I} \times X_{I}$ & & & & -0.000002 & -0.0781 \\
\hline$X_{2} \times X_{2}$ & & & & -0.000005 & -0.0584 \\
\hline$X_{3} \times X_{3}$ & & & & -0.000001 & -0.0593 \\
\hline$X_{4} \times X_{4}$ & & & & -0.0505 & -0.1900 \\
\hline$X_{5} \times X_{5}$ & & & & -0.0000065 & -0.1438 \\
\hline$X_{6} \times X_{6}$ & & & & -0.0502 & -0.3520 \\
\hline$X_{7} \times X_{7}$ & & & & 0.00000003 & 0.0021 \\
\hline \multicolumn{6}{|c|}{ Moderating Effect from Climate } \\
\hline \multicolumn{6}{|c|}{ Factors } \\
\hline$X_{5} \times X_{I}$ & & & & 0.00002 & 0.4272 \\
\hline$X_{5} \times X_{2}$ & & & & 0.00004 & 0.6518 \\
\hline$X_{5} \times X_{3}$ & & & & 0.00001 & 0.1461 \\
\hline$X_{5} \times X_{4}$ & & & & 0.0010 & 0.1930 \\
\hline$X_{6} \times X_{I}$ & & & & -0.0010 & -0.2937 \\
\hline$X_{6} \times X_{2}$ & & & & -0.0033 & -0.4602 \\
\hline$X_{6} \times X_{3}$ & & & & -0.0016 & -0.3888 \\
\hline$X_{6} \times X_{4}$ & & & & -0.0972 & -0.2110 \\
\hline$X_{7} \times X_{I}$ & & & & 0.000003 & 0.1447 \\
\hline$X_{7} \times X_{2}$ & & & & -0.000002 & -0.0459 \\
\hline$X_{7} \times X_{3}$ & & & & -0.000003 & -0.1279 \\
\hline$X_{7} \times X_{4}$ & & & & -0.0003 & -0.0779 \\
\hline R-squared & 0.8810 & 0.8810 & & 0.9490 & \\
\hline Adjusted R-squared & 0.8616 & 0.8616 & & 0.8937 & \\
\hline Reset Test P-value & 0.0006 & 0.0006 & & 0.8549 & \\
\hline White Test P-value & 0.0163 & 0.1309 & & 0.3211 & \\
\hline DW Test & 0.7140 & 0.8455 & & 1.4262 & \\
\hline F-statistics (Prob) & $45.4826(<0.01)$ & 45.4826 & $(<0.01)$ & 17.1720 & $(<0.01)$ \\
\hline
\end{tabular}

Note: Coefficient estimates in bold face and italic are significant at the 5\% level. 


\section{References}

[1] Ahmed, M., Sultan, M., Wahr, J., Yan, E., 2014. The use of GRACE data to monitor natural and anthropogenic induced variations in water availability across Africa. Earth-Sci Rev 136, 289-300.

[2] Bailey, T.C., Gatrell, A.C., 1995. Interactive spatial data analysis. Longman Scientific \& Technical, Harlow.

[3] Chapman, G.B., Johnson, E.J., 2003. Incorporating the irrelevant anchorsing judgements of belief and value. Cambridge University Press., UK.

[4] Chou, W.W., Lee, S.H., Wu, C.F., 2014. Evaluation of the Preservation Value and Location of Farm Ponds in Yunlin County, Taiwan. Int J Env Res Pub He 11, 548-572.

[5] Clayton, J., MacKinnon, G., 2001. The Time-Varying Nature of the Link between REIT, Real Estate and Financial Asset Returns. Journal of Real Estate Portfolio Management 7, 43-54.

[6] Clayton, J., MacKinnon, G., 2003. The relative importance of stock, bond and real estate factors in explaining REIT returns. J Real Estate Financ 27, 39-60.

[7] Cobbinah, P.B., Erdiaw-Kwasie, M.O., Amoateng, P., 2015. Rethinking sustainable development within the framework of poverty and urbanisation in developing countries. Environmental Development 13, 18-32.

[8] Cohen, B., 2006. Urbanization in developing countries: Current trends, future projections, and key challenges for sustainability. Technology in Society 28, 63-80.

[9] Cressie, N.A.C., 1993. Statistics for spatial data, Rev. ed. Wiley, New York ; Chichester.

[10] Das, B., Singh, A., Panda, S.N., Yasuda, H., 2015. Optimal land and water resources allocation policies for sustainable irrigated agriculture. Land Use Policy 42, 527-537.

[11] Eduful, M., Shively, D., 2015. Perceptions of urban land use and degradation of water bodies in Kumasi, Ghana. Habitat International 50, 206-213.

[12] EEA, 2012. Report: European waters - assessment of status and pressures. European Environment Agency, European.

[13] Gibbs, L.M., 2010. Troubled Waters: Confronting the Water Crisis in Australia's Cities. Urban Stud 47, 222-224.

[14] Gyau-Boakye, P., Biney, C.A., 2002. Management of Freshwater Bodies in Ghana. Water International 27, 476-484.

[15] Ismaiylov, G.K., Fedorov, V.M., 2001. Analysis of Long-Term Variations in the Volga Annual Runoff. Water Resources 28, 469-477.

[16] Jacowitz, K.E., Kahneman, D., 1995. Measures of Anchoring in Estimation Tasks. Personality and Social Psychology Bulletin 21, 1161-1166.

[17] Javi, S.T., Malekmohammadi, B., Mokhtari, H., 2014. Application of geographically weighted regression model to analysis of spatiotemporal varying relationships between groundwater quantity and land use changes (case study: Khanmirza Plain, Iran). Environ Monit Assess 186, 3123-3138.

[18] Jothityangkoon, C., Hirunteeyakul, C., Boonrawd, K., Sivapalan, M., 2013. Assessing the impact of climate and land use changes on extreme floods in a large tropical catchment. J Hydrol 490, 88-105.

[19] Kahneman, D., Tversky, A., 1979. Prospect Theory: An Analysis of Decision under Risk. 
Econometrica 47, 263-291.

[20] Kwan, M.P., 2000. Interactive geovisualization of activity-travel patterns using three-dimensional geographical information systems: a methodological exploration with a large data set. Transport Res C-Emer 8, 185-203.

[21] Lambin, E.F., Meyfroidt, P., 2010. Land use transitions: Socio-ecological feedback versus socio-economic change. Land Use Policy 27, 108-118.

[22] Le Maitre, D.C., Kotzee, I.M., O'Farrell, P.J., 2014. Impacts of land-cover change on the water flow regulation ecosystem service: Invasive alien plants, fire and their policy implications. Land Use Policy 36, 171-181.

[23] Li, H., Huang, X., Kwan, M.-P., Bao, H.X.H., Jefferson, S., 2015. Changes in farmers' welfare from land requisition in the process of rapid urbanization. Land Use Policy 42, 635-641.

[24] Liu, J., Yang, W., 2012. Water Sustainability for China and Beyond. Science 337, 649-650.

[25] Lizieri, C., 2013. After the Fall: Real Estate in the Mixed-Asset Portfolio in the Aftermath of the Global Financial Crisis. J Portfolio Manage 39, 43-52.

[26] Long, H.L., 2014. Land use policy in China: Introduction. Land Use Policy 40, 1-5.

[27] Luo, S.L., Wang, H.J., Cai, F., 2013. An integrated risk assessment of coastal erosion based on fuzzy set theory along Fujian coast, southeast China. Ocean Coast Manage 84, 68-76.

[28] Mehta, L., 2014. Water and Human Development. World Dev 59, 59-69.

[29] Montanari, A., Young, G., Savenije, H.H.G., Hughes, D., Wagener, T., Ren, L.L., Koutsoyiannis, D., Cudennec, C., Toth, E., Grimaldi, S., Blöschl, G., Sivapalan, M., Beven, K., Gupta, H., Hipsey, M., Schaefli, B., Arheimer, B., Boegh, E., Schymanski, S.J., Di Baldassarre, G., Yu, B., Hubert, P., Huang, Y., Schumann, A., Post, D.A., Srinivasan, V., Harman, C., Thompson, S., Rogger, M., Viglione, A., McMillan, H., Characklis, G., Pang, Z., Belyaev, V., 2013. "Panta Rhei-Everything Flows": Change in hydrology and society-The IAHS Scientific Decade 2013-2022. Hydrological Sciences Journal 58, 1256-1275.

[30] Nace, R.L., 1980. Hydrology comes of age: Impact of the International Hydrological Decade. Eos, Transactions American Geophysical Union 61, 1241-1241.

[31] Oki, T., Kanae, S., 2006. Global Hydrological Cycles and World Water Resources. Science 313, 1068-1072.

[32] Ou, Y., Wang, X.Y., Geng, R.Z., 2014. Assessment of Spatio-Temporal Patterns of Water Quality and Apportionment of Pollution Soueces in the Water Supply Watershed of Bejing, China. Fresen Environ Bull 23, 408-417.

[33] Shindu, P.S., Govindaru, V., 2014. Spatio-Temporal Change of Crop Diversification in Kerala: An Economic Review. Adv Geogr Eviron Sci, 129-136.

[34] Silverman, B.W., 1986. Density estimation for statistics and data analysis. Chapman and Hall, London.

[35] Strack, F., Mussweilert, E., 1997. Explaining the estimate anchoring effect mechanisms of selective accessibility. Journal of Personality and Social Psychology 73, 437-446.

[36] UN-Habitat, 2009. Planning sustainable cities: Global report on human settlements. Sterling, London. 
[37] Williams, P., 1989. Adapting Water-Resources Management to Global Climate Change. Climatic Change 15, 83-93.

[38] Yang, H., Flower, R.J., Thompson, J.R., 2013. Sustaining China's Water Resources. Science 339, 141.

[39] Yang, Y., Liu, Y., 2014. Spatio-temporal analysis of urbanization and land and water resources efficiency of oasis cities in Tarim River Basin. J Geogr Sci 24, 509-525.

[40] Yin, Y., Chen, Y., Yu, S., Xu, W., Wang, W., Xu, Y., 2013. Maximum water level of Hongze Lake and its relationship with natural changes and human activities from 1736 to 2005. Quaternary International 304, 85-94.

[41] Zhai, X.Y., Xia, J., Zhang, Y.Y., 2014. Water quality variation in the highly disturbed Huai River Basin, China from 1994 to 2005 by multi-statistical analyses. Sci Total Environ 496, 594-606.

[42] Zhang, C., Li, Y., Lv, S.H., Fang, J.D., Teng, Y.G., Zhang, H.B., Li, D.Q., 2013. Evaluation of Urbanized Ecological Environment Quality: A Case Study on Beijing Chaoyang District. Environ Eng Manag J 12, 1779-1784.

[43] Zheng, S., Geng, B., Wu, X., Lv, L., Hu, Y., 2014. Performance Evaluation of Industrial Land Policy in China. Sustainability, 6, 4823- 4838.

[44] Zhou, D.C., Luo, G.P., Lu, L., 2010. Processes and trends of the land use change in Aksu watershed in the central Asia from 1960 to 2008. J Arid Land 2, 157-166. 